Chapter 4

\title{
Congenital Hypothyroidism: Effects on Linear Growth, Catch-Up Growth, GH-IGF-I Axis and Bones
}

\author{
Ashraf T. Soliman, Vincenzo De Sanctis and \\ El Said M.A. Bedair \\ Additional information is available at the end of the chapter \\ http://dx.doi.org/10.5772/53317
}

\section{Introduction}

Triiodothyronine (T3) is a primary determinant of normal postnatal somatic growth and skeletal development, and an important regulator of bone and mineral metabolism in human [1, 2]. Before puberty, thyroid hormone appears to be a major prerequisite for normal maturation of bone [3]. Untreated childhood hypothyroidism results in a profound growth retardation and a delayed skeletal maturation. In severe cases, linear growth is almost completely halted. When treatment occurs, growth often resumes at a rate faster and beyond the normal rate for age [3, 4]. This phase of accelerated growth constitutes the "catch-up growth" phenomenon. This may be complete or incomplete depending upon many factors including the age at presentation, the severity of hypothyroidism and its duration, the age at diagnosis, and the genetic target height.

Thyroid hormones are among the important direct biological regulators of growth plate and bone accretion. In addition, thyroid hormones influence and interact with the growth hormone $(\mathrm{GH})$ - Insulin-like growth factor-I (IGF-I) system and other hormones that control stature and bone growth. Hypothyroid patients show low plasma levels of IGF-I and reduced IGF bioactivity, whereas hyperthyroid patients present high plasma IGF-I levels and also low IGF bioactivity. [5] Similar changes have been observed in rats [6]. Besides, a decrease in hepatic IGF-I messenger RNA (mRNA) expression in experimental hypothyroid animals has been reported [7]. In experimental animals the effects of thyroid hormone on the IGFs system can be GH mediated [11] or non-GH mediated [12-14]. The interrelationships between the thyroid function and pituitary GH/serum IGFs axis are complex and not fully understood. GH treatment does not restore serum IGF-I levels in hypothyroid rats [6]. Decreased serum IGF-I levels in hypophysectomized rats increase after treatment with T4 
doses in vivo, in a way significantly greater than after GH administration [15], an effect which is not observed in vitro, suggesting the presence of factors, other than $\mathrm{GH}$, involved in the regulation of this axis in vivo.

In human, T4 replacement increases the serum levels of IGF-I and ALS in patients with primary as well as central hypothyroidism [16]. Hypothyroidism in childhood is almost invariably associated with growth failure. After the onset of T4 replacement therapy, growth and skeletal abnormalities usually resolve and a period of catch-up growth ensues. In the past, it has been suggested that catch-up growth in children treated for congenital or juvenile hypothyroidism is complete, and that such children usually reach their expected adult height [17-21], but this is not supported by recent reports showing a failure of catch-up growth in children in whom treatment has been initiated after a long period of untreated hypothyroidism [22-24].

Several mechanisms can contribute to the pathophysiology of growth failure associated with hypothyroidism. These include: abnormalities of GH secretion, IGF-I synthesis and direct action of low thyroxine on growth plate and skeletal growth. [16-19, 24, 25]

\section{Postnatal Phases of Growth (Infantile-Childhood-Pubertal (ICP) pattern)}

Stature growth is characterized by a pattern of changing height velocity from infancy to adulthood. A high velocity from birth with a rapid deceleration up to about $3 \mathrm{yr}$ of age is seen, followed by a period with a lower and slowly decelerating velocity up to puberty. Puberty starts with an increased velocity and after the age of peak velocity a deceleration is observed until growth ceases. This pattern of growth is known as the infantile-childhoodpuberty (ICP) pattern. [26-28]

\section{Catch-up growth and patterns of catch-up growth}

Catch-up growth is the compensatory total increase in the stature growth, either by increasing the growth velocity and/or by increasing the duration of total growth (delaying growth plate closure), after correction of the limiting factor that inhibited growth. Catch-up growth may be complete or incomplete. Catch-up growth is considered to be complete for an individual child if his final height is within the target range. In groups of patients, complete catch-up growth is expected to result in a mean final height close to the mean target height. Resumption of a normal height velocity once the growth-suppressing problem has been resolved with a return to and then maintenance of normal height growth velocity (GV) does not lead to any catch-up growth as the loss in height standard deviation score (HtSDS) is permanent (not compensated) [26-28]. 


\subsection{Patterns of catch-up growth}

Three different types of catch-up growth can be distinguished: Type A is common in infancy and early childhood. When growth restriction ceases, height velocity increases up to 4 times the mean velocity for chronological age in order to compensate rapidly and fully for the height deficit. Once the original curve is re-approached, height velocity returns to normal. A classic example of catch-up growth type A occurs after institution of a gluten-free diet in childhood celiac disease. In catch-up growth type B a small or no increase of height velocity occurs after the growth restriction has ceased as compared with the mean velocity for chronological age. However, growth continues for longer than usual, so that ultimately the growth arrest is compensated. Type $\mathrm{C}$ is a mixture of types $\mathrm{A}$ and $\mathrm{B}$. When growth restriction ceases, there is an increase in height velocity as well as a delay and prolongation of growth. [26-32]

A catch-up process that brings a child to the 50th percentile or above, for a given population $(\mathrm{HtSDS}=$ or $>0)$ is considered complete. A catch-up that brings a child to $>-2$ but below 0 is considered incomplete. Complete catch-up growth may be also accepted when the child attains a final height within the genetic potential range (Mid-parental height) (+/- 1 SD) [26].

It has been suggested that acceleration of growth velocity rather than delayed maturation occurs during infancy and early childhood; but during late childhood and adolescence delayed maturation rather than acceleration of growth velocity occurs. This can be explained by the progressive fall of growth plate chondrocyte proliferation, and hence the reduced potential for catch-up with age [26-32].

Canalization means that the individual growth curve parallels the percentile curves of growth charts. In the pre-pubertal period, canalization is clearly seen and therefore a catchup growth spurt is easily recognizable. However, during pubertal years, catch-up growth may not be clearly separated from pubertal growth spurt [26].

\section{Regulation of postnatal longitudinal bone growth}

Longitudinal bone growth is achieved by the complex, multistep process known as endochondral ossification, whereby the cartilaginous template of the axial and appendicular skeleton is replaced by bone. This process is initiated when chondrocytes at the epiphyseal growth plate are stimulated to proliferate and then proceed through stages of maturation and hypertrophy. In the region of cellular hypertrophy, the surrounding matrix and vascular tissue undergo calcification. The hypertrophic chondrocytes degenerate and give way to invading osteoblasts, and bone and bone marrow subsequently replace the calcified cartilage at the metaphysis. Endochondral ossification is an important determinant of both the rate and extent of longitudinal bone growth. This growth plate activity is in turn subject to regulation by a number of factors, which might be of genetic, endocrine, paracrine, and autocrine origin. It is the complex interactive effects of these substances on chondrocytes in vivo that determine the final growth response. Endocrine regulators include various hor- 
mones such as thyroid hormones, GH, parathyroid hormone/parathyroid hormone related peptide (PTH/PTHrP), as well as several growth factors and cytokines, such as IGF-I and basic fibroblast like growth factor. [32-36]

\section{Effect of thyroxine on growth plate and bones}

Long bones are formed by endochondral ossification and the skull by intramembranous ossification. During endochondral ossification, mesenchyme-derived chondrocytes form a cartilage model, undergo hypertrophic differentiation and then apoptose. The surrounding collagen X-rich cartilage matrix calcifies and forms a scaffold for bone formation by osteoblasts. Organized columns of proliferating and differentiating chondrocytes persist in the growth plate until adolescence and mediate linear growth and the acquisition of peak bone mass. The epiphyses and metaphyses of long bones originate from separate ossification centers that are separated by a growth plate. By contrast, in intramembranous ossification, osteoblasts differentiate from mesenchyme to form bone directly. Adult bone structure and mechanical strength are preserved by a continuous process of skeletal remodelling during which precise coupling of osteoclastic bone resorption and subsequent osteoblastic bone formation is maintained. [37]

Hypothyroidism slows longitudinal bone growth and endochondral ossification, while hyperthyroidism accelerates both processes. In hypothyroid animals, there is a decrease in the heights of the proliferative and hypertrophic zones, and a decrease in chondrocyte proliferation and chondrocyte hypertrophy and disruption of the normal columnar organization of the growth plate and vascular/bone cell invasion. T3 seems to stimulate the recruitment of cells to the proliferating zone from the germinal zone and facilitate the differentiation of growth plate chondrocytes. [38,39] In thyroid receptor (TRa) knockout mice [40] there is a complete growth arrest, with disorganization of epiphyseal growth plate chondrocytes and delayed cartilage mineralization and bone formation. These abnormalities result from severe hypothyroidism due to impaired thyroid hormone production at weaning, as the skeletal phenotype can be rescued by T4 replacement. [40] In the hypothyroid rat, proliferating chondrocytes fail to form discrete columns and the hypertrophic zone is diminished in width and morphologically indistinct. Expression of collagen $X$, a specific marker of hypertrophic chondrocyte differentiation is undetectable in the hypothyroid growth plate, indicating that hypertrophic chondrocyte differentiation is severely impaired.

The growth plate is separated from the primary spongiosum by a mineralised interface, essentially sealing off the growth plate from vascular invasion and preventing further bone lengthening, leading to growth retardation. During hypothyroidism, there is disruption of the normal functional continuity between maturing chondrocytes and mineralizing osteoblasts with markedly reduced osteoblast invasion and fewer, thinner bone trabecula. T4 induces the expression of both type II and X collagen, the activity of the differentiation marker alkaline phosphatase, and chondrocyte hypertrophy. [38-40] 
In addition, the growth plates of hypothyroid rats also have abnormal cartilage matrix deposition. Normal cartilage matrix is composed of proteoglycans containing chondroitin and heparan sulfates and hyaluronic acid residues. In hypothyroid rats, studies have revealed an abnormal increase in sulfation of heparan sulfate proteoglycans in proliferating chondrocytes. This abnormal matrix is deposited in a patchy irregular fashion suggesting that thyroid hormones influence extra-cellular matrix biology as well as cellular activity of the growth plate. Treatment of these rats with thyroid hormones reverses these changes and studies have shown that this is through the direct actions of T3 on bone, and it is not growth hormone (GH) mediated [38]. T4 but not $\mathrm{GH}$ is capable of completely reverting reduced widths of the proliferating and hypertrophic zone, as well as a disturbed growth plate architecture and vascular invasion of the growth plate in hypothyroid rats, establishing a unique role for thyroid hormones in the regulation of bone growth and maturation [39-44].

In vitro, thyroid hormones also stimulate terminal differentiation of epiphyseal growth plate chondrocytes. [45] Tibial dyschondroplasia (TD), a disorder of broiler chickens, associated with avascular non-mineralised cartilage extending from the epiphyseal growth plate, results from the inability of proliferating chondrocytes to undergo terminal differentiation to hypertrophic chondrocytes. This disorder has been shown to be associated with a markedly reduced expression of iodothyronine deiodinase type 2 (DIO2) in the growth plate [14]. DIO2 acts by catalysing the conversion of T4 to T3. Epiphyseal dysgenesis ( Figure 3) in hypothyroidism can be similarly explained by a reduction in T3 which is necessary to stimulate resting zone cells to proliferate and differentiate into chondrocytes, and for vascular invasion of the growth plate [46, 47].

Indian hedgehog (Ihh) is a member of the hedgehog family of secreted ligands and is a master regulator of bone development. Ihh is synthesized by prehypertrophic and hypertrophic chondrocytes [48, 49]. Ihh stimulates production of parathyroid hormone-related peptide (PTHrP) from cells at the periarticular ends of bones. PTHrP acts on the PTH/PTHrP receptor (PPR) to keep proliferating chondrocytes in the proliferative pool. When the source of PTHrP is sufficiently distant, the chondrocytes are no longer stimulated by PTHrP and they stop proliferating and start to synthesize Ihh. In addition, Ihh stimulates chondrocyte proliferation directly and also controls the differentiation of osteoblasts from perichondrial cells during the formation of the bone collar. Thus, interactions between Ihh and PTHrP determine the lengths of proliferating columns of chondrocytes in the growth plate and hence the pace of bone growth. In hypothyroid animals Ihh is mainly located within the upper regions of the proliferative zone and the reserve zone [50]. PTHrP mRNA expression is also altered in the hypothyroid growth plate. Levels of expression are increased and include expression by chondrocytes extending throughout the proliferative and reserve zones. PTH/PTHrP receptor (PPR) is also altered by thyroid status. It is expressed throughout all zones of the growth plate in euthyroid and hypothyroid animals, and restricted to proliferative and prehypertrophic chondrocytes in hypothyroid-T4 treated rats. Thyroid hormone has been shown to stimulate terminal differentiation of growth plate chondrocytes by down regulation of Sox9, a transcription factor present in cells of mesenchymal condensations and proliferating chondrocytes but not in hypertrophic chondrocytes [51]. This terminal 
differentiation process is associated with expression of cyclin-dependant kinase inhibitors known to regulate the cell cycle checkpoint [52].

These data strongly support a role for thyroid hormones in regulating components of the Ihh/PTHrP feedback loop in the growth plate and thus the pace of chondrocyte differentiation and bone growth.

Fibroblast Growth Factor Receptor-1 (FGFR1) is a T3-target gene in bone. Three FGFRs are known to be essential for skeletal development. Mutations of all three FGFRs can cause variable bony abnormalities, while an activating mutation of FGFR3 is the cause of achondroplasia, the most common genetic form of dwarfism [53, 54]. FGFR1 has been identified as a T3target gene in osteoblasts [55]. T3 acting via the thyroid hormone receptor (TR) enhances FGF stimulation of FGFR1 activity. Hypothyroid mice display delayed endochondral ossification and have abnormalities of cartilage matrix similar to those described above, namely an increase in heparan sulfate proteoglycans [54]. It is known that heparan sulfate is required for binding of FGF to FGFR and for ligand-induced receptor activity [56, 57]. Therefore, T3-regulated production of heparan sulfate, or modification of its structure, might be the mechanism by which T3 regulates FGFR1 signalling. In addition to the thyroid hormone receptors, receptors for growth hormone (GH), insulin like growth factor-1 (IGF-1), are also expressed by growth plate chondrocytes [58-60]. T3 influences expression of several components of GH/IGF-1 signalling in bone [61, 62].

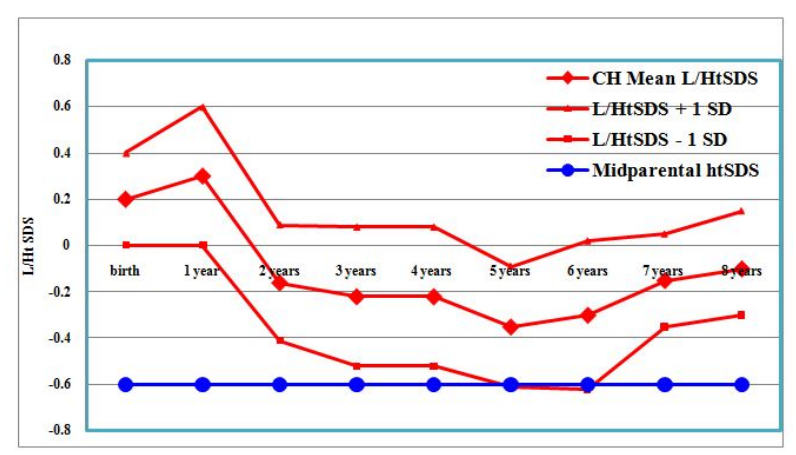

Figure 3. Effect of thyroxine treatment on infants and children with congenital hypothyroidism (CH) (infantile and childhood phases) growth diagnosed through neonatal screening compared to their mid-parental height (MPHtSDS).

In summary, thyroid hormones act through chondrocytes bearing TRs to modulate growth plate proliferation, differentiation, and vascular invasion. These functions are mediated via many possible mechanisms including direct action on the chondrocytes, osteoblasts and mast cells, as well through interaction with other hormones and growth factors acting in endocrine, paracrine and autocrine fashions. Understanding the mechanisms behind the interactions between the T3 signaling pathway and the systemic and paracrine effects of GH/ IGF-1 is important in considering the molecular biology of thyroid hormone-dependent skeletal development. 


\section{Effect of hypothyroidism on bone remodelling and skeleton}

Remodelling is crucial for bone health, which is characterized by simultaneous formation and resorption. Thyroid hormones affect bone cells both in vitro and in vivo by stimulating osteoblast and osteoclast cells with more bone resorption and increased skeletal remodelling. Thyroid hormone status within the physiological range affects bone mass and density. In healthy men at age of peak bone mass, between-subject variation in thyroid hormone concentrations affects bone density. Higher levels of FT3, TT3, TT4 and TBG are associated with less favourable bone density and content [63-65].

In experimental adult dogs, thyroxine administration in moderate pharmacologic doses increased the activation frequency, number of bone-forming and -resorbing sites, and the osteoid seam circumference in unaltered bone. Thyroxine, by activating skeletal remodelling, increases bone turnover and both formation and resorption at the tissue level. The increased serum calcium and phosphorus levels and urinary hydroxyproline excretion at several intervals during thyroxine administration are consistent with the morphometric evidence of increased bone turnover and resorption. These findings suggest that thyroxine is a potent activator of skeletal remodelling. [66]

In sheep, thyroidectomy at 105-110 days of gestation results in very low levels of foetal plasma T4 and T3 (no pre-partum rise in fetal plasma T3) and the foetuses have shorter bones and altered metatarsal structure and strength when analysed at or close to term $(145 \pm 2$ days). At and just before term the thyroidectomised sheep data indicated that the structural changes in bone are a result of impaired bone formation whilst resorption was normal. These changes resemble the phenotype reported in adult D2 knockout mice but the precise cellular basis is not known [67]. The reduced bone formation may be a consequence of local effect of T3 on the bones or due to altering signalling pathways such as the GH/IGFI axis which is known to be anabolic to the skeleton.

In human, overt hyperthyroidism is associated with increased bone resorption, low bone mineral density and increased number of fractures in postmenopausal women [68-70]. Both hyperthyroidism and to some extent hypothyroidism are linked to reduction of bone mineral density and, hence, increased risk for fracture. Low thyroid hormone levels, rather than the increased TSH levels, are responsible for the decreased bone resorption during hypothyroidism in thyroid carcinoma patients. The levels of C-cross linking terminal telopeptide of type 1 collagen were lower during hypothyroidism compared to 8 weeks after reinstitution of thyroxine replacement therapy [71,72].

Clinically, the radiological skeletal manifestations of congenital and severe juvenile hypothyroidism include:

a. in the long bones: delay in the appearance of ossification centres (delayed bone age), deformed and irregular shape (epiphyseal dysgenesis) of the already existing centres and metaphyseal widening (splaying);

b. in the skull: the presence of the intrasutural (wormian) bones, widening of the sutures and fontanelles, delayed closure of fontanelle and delayed teeth eruption, 
c. in the vertebrae : abnormal flattening, bulleting and inferior lipping and

d. broadening of ribs $[73,74]$.

These radiological changes appeared similar in many aspects to those reported in mucopolysaccharidosis (MPS) and can be explained by the previously mentioned abnormalities in the growth plate chondrocytes, bone cells and matrix [72,75] (Figure 3).

\section{Effect of thyroxine on Growth hormone-Insulin-like growth factor-I system}

In addition to its local action on the growth plate, thyroid hormones may have indirect effects on the growth plate, mediated by GH and IGF-I. In hypothyroid humans and mice, GH and IGF-I levels are reduced and IGF-I generation is defective. In addition to the local action of thyroxine on growth plate, treatment with thyroxine increases IGF-I secretion and improves IGF-I generation associated with increased growth rate. Moreover, thyroid hormones have been shown to interact with the GH-IGF-I pathway at the level of the growth plate. T3 was shown to promote proliferation of embryonic chicken chondrocytes and cultured rat epiphyseal chondrocytes by enhancing IGF-I mRNA expression. T3/T4 can regulate growth hormone receptor (GHR) expression, in vivo in rat growth plates [75-77].

The effects of T3 and IGF-I on (3H) thymidine incorporation, alkaline phosphatase (ALP) activity and IGF-I receptor mRNA levels are studied in rat epiphyseal chondrocytes cultured in monolayer. ALP activity (a late marker of differentiated epiphyseal chondrocytes) is increased by $\mathrm{T} 3$ in a dose-dependent manner with a maximal response at 10 micrograms. IGFI receptor mRNA levels were increased by 10 micrograms of T3 while no effect of hGH (50 micrograms/l) or IGF-I (25 micrograms/l) was demonstrated. Both T3 and IGF-I are shown to interact with epiphyseal chondrocytes and both substances seem to affect cell proliferation and maturation and therefore longitudinal bone growth. These results indicate that IGF-I is important for proliferation of the cells while T3 initiates the terminal differentiation of epiphyseal chondrocytes [78].

In children with hypothyroidism Soliman et al. [73] have reported a significant decrease of GH response to Clonidine stimulation as well as a decreased IGF-I generation in response to GH stimulation. IGF-I generation shows a small but significant increase in the IGF-I production in response to the exogenous GH. The mean peak is lower than $100 \mathrm{ng} / \mathrm{ml}$, which is the cut off to define GHD stated in the normative data. [73]. This limited, yet significant IGF-I generation after $\mathrm{GH}$ administration suggests that the GHD associated with the hypothyroid state was not the sole explanation to the low IGF-I level and supports the possibility of associated GH insensitivity (GHI) state and/or a direct role of thyroxine on hepatic IGF-I production not mediated via GH. In hypothyroid patients, after treatment with thyroxine, marked improvement in the IGF-I generation occurs but this is still lower compared to normal children. Cavaliere $\mathrm{H}$ et al. [79] have found significantly decreased basal IGF-I concentrations in primary hypo- 
thyroid and endemic cretins with a significant increase after treatment and have described a positive correlation $(r=0.56)$ between IGF-I and serum T4 and T3 concentrations.

In the mature hypothyroid rats, serum IGF-I levels are partially corrected by GH but are normalised by thyroid hormone replacement [80].

Gaspard T et al. [81] reported that the administration of T4 alone to hypophysectomized or thryoidectomized animals was capable of stimulating the IGF-I activity in the absence of GH. Romos S et al., [82] reported good positive correlation between IGF-I and thyroid hormone concentrations in both neonatal and adult thyroidectomized rats and that the correlation between them was dependent on the dose of T4. Also, Ikeda T et al. [83] stated that the T3, but not T4, directly enhances the release and synthesis of IGF-I in a dose dependent manner in the rat liver. T3 also controls the IGF-I biosynthesis in nerve cells in rats [84]. Collectively, the effects of thyroid hormone on serum IGF levels seem to be mediated only partially via GH but other effects involving either direct thyroid hormone effects, or mediated by some other route, independent of GH, appear to be working.

In children with hypothyroidism, in spite of significant improvement of IGF-I levels after treatment versus before treatment, IGF-I generation is still significantly below age-matched normal children. This defective IGF-I production after treatment suggest that prolonged hypothyroidism may modulate the IGF-I secreting ability of the hepatocytes either through negative effect on their mass (number or size) and/or on the expression of the GHR on their surfaces. In sheep, induction of the hepatic GH receptor and the maturational switch in hepatic IGF-I synthesis are initiated by the pre-partum rise in foetal plasma cortisol $[85,86]$. Cortisol also stimulates deiodination of thyroxin (T4) to triiodothyronine (T3) and thereby leads to a pre-partum rise in plasma T3 that coincides with the increase in hepatic GH receptor and IGF-I gene expression toward term [86].

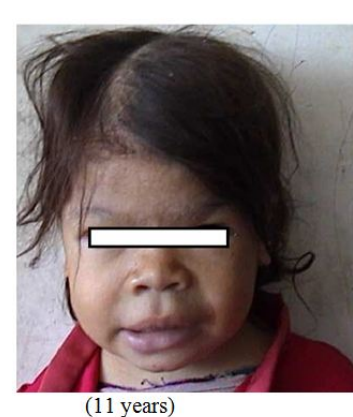

(11 years)

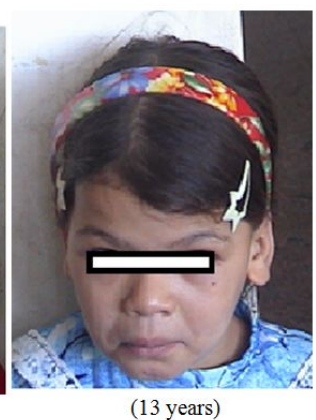

(13 years)

Figure 1. Photograph of patient demonstrating her coarse facial features before treatment [11 years] and improvement after treatment.

Forhead AJ et al., [87] have reported that thyroid hormones regulate hepatic growth hormone receptor (GHR) and IGF-I gene expression in the sheep fetus during late gestation. Thyroid hormone deficiency induced by foetal thyroidectomy abolished the normal pre-par- 
tum rise in hepatic GHR mRNA abundance. However, the precise mechanisms by which T3 acts on the GHR gene are unclear [88]. Nuclear thyroid hormone receptors are present in foetal ovine liver during late gestation and have a 10-fold greater affinity for T3 than T4 in utero [89].

The effect of thyroid hormone on the regenerative capacity of hepatocytes may be important. Moro L et al. [89] and Alisi A et al., [90] have proved the role of thyroid hormones on the regenerative capacity of the liver which was reduced during the hypothyroid state and regained to normal after thyroid hormone administration through altering the expression of the proteins involved in the control of cell cycle and apoptosis, decreasing tissue rate of protein synthesis, and retarding growth of the liver and the whole animal [91,92]. These studies propose an important role of thyroid hormones on the hepatocyte regenerative power and the GHR expression on hepatocytes and suggest that thyroxine deficiency may compromise these functions and dependent loss of IGF-I production capacity.

In adults with GH deficiency, GH administration stimulates peripheral T4 to T3 conversion in a dose-dependent manner. Serum T3 levels are subnormal despite T4 substitution when the patients are off GH but normalised with GH therapy. Energy expenditure increases with GH and correlates with free T3 levels. GH causes a significant blunting of serum TSH. These findings suggest that GH plays a distinct role in the physiological regulation of thyroid function in general, and of peripheral T4 metabolism in particular [93].

Untreated primary hypothyroidism is associated with decreased GH pulsatility, attenuation of GH response to secretagogues and a reduction in IGF-I and IGF Binding Protein-3 (IGFBP-3). Reduced levels of IGF-I that increase with L-thyroxine replacement therapy have also been demonstrated in the setting of subclinical hypothyroidism [94,95]. Conversely, hyperthyroidism is associated with an increase in mean 24 hour GH concentration and secretion rates [96, 97] while serum IGF-I and IGFBP-3 levels have been found to be normal in subclinical hyperthyroidism [84] with a normal or high [94, 98, 99] IGF-I in overt thyrotoxicosis. Administration of T4 to hypophysectomised animals has been shown to stimulate IGF-1 production in the absence of GH, while IGF-BP3 was shown to be GH dependent [100].

In summary, thyroid hormones modulate growth plate growth and part of this effect appears to be mediated by activating GH-IGF-I axis and modulating local GH and/or IGF-I actions.

\section{Thyroxine and catch-up growth}

Evidence from animal studies suggests that catch-up growth is due, in large part, to a delay in growth plate senescence. Growth plate senescence refers to the normal, programmed changes that occur in the growth plate over time i.e. growth plate chondrocytes may have a finite proliferative capacity that is gradually exhausted, causing growth to slow and eventually to stop. With increasing age, there is a decrease in the linear growth rate, the chondrocyte proliferation rate, the height of the growth plate, and the number of cells in each growth plate zone. Growth plate senescence is not a function of time per se, but of cell proliferation. Hypothyroidism suppresses growth plate chondrocyte proliferation, but it con- 
serves the proliferative capacity of the chondrocytes and therefore it slows their senescence. Consequently, after transient growth inhibition, growth plates retain a greater proliferative capacity, are less senescent, and, hence, show a greater growth rate than expected for age, resulting in catch-up growth [101,102].

Marino R et al. [102] have administered propylthiouracil to newborn rats for $8 \mathrm{wk}$ to induce hypothyroidism and then stopped the propylthiouracil to allow catch-up growth. In untreated controls, the growth plates undergo progressive, senescent changes in multiple functional and structural characteristics. In treated animals, after stopping propylthiouracil, these functional, structural, and molecular senescent changes are delayed, compared with controls. This delayed senescence includes a delayed decline in longitudinal growth rate, resulting in catch-up growth. These findings demonstrate that growth inhibition due to hypothyroidism slows the developmental program of growth plate senescence, including the normal decline in the rate of longitudinal bone growth, thus accounting for catchup growth.

A proportion of patients with T3 resistance, caused by mutant T3 receptor proteins, suffer from growth retardation and developmental abnormalities of bone $[103,104]$ that reflect tissue hypothyroidism. T4 replacement induces rapid catch-up growth, although this may be incomplete because bone age advances faster than the increase in height [105].

The deficit in final height after treatment appears to correlate with the severity and duration of hypothyroidism. Catch-up growth may be especially compromised if treatment is required at or around the onset of puberty. Boersma B et al, [106] reported that if catch-up growth coincides with the pubertal growth spurt, final height might be compromised, possibly due to very rapid bone maturation. Soliman et al. [73] found that treatment of elder children with neglected hypothyroidism accelerates their bone maturation in the first year of treatment (bone age delay changed from $4.7+/-1$ years to $3.1+/-0.9$ years after a year of therapy). In accordance with this, childhood thyrotoxicosis causes accelerated growth and advanced bone age, which may lead to craniosynostosis, premature growth plate closure, and a short stature [107].

\section{Growth in Congenital and Juvenile Hypothyroidism Before Versus After Thyroxine Treatment}

Poor length growth is apparent as early as the first year of life. Before the neonatal screening was initiated in the 1970s, the percentage of children with congenital hypothyroidism $(\mathrm{CH})$ having a height below the 10th percentile has been shown to range from 19\% to $31 \%$. Adult stature without treatment ranges from 1 to 1.6 metres, depending on severity, sex and other genetic factors. Bone maturation and puberty are severely delayed. Ovulation is impeded and infertility is common. Growth arrest, delayed bone age, and epiphyseal dysgenesis occur in congenital hypothyroidism, juvenile hypothyroidism and in some patients with resistance to thyroid hormone, whereas accelerated growth and skeletal maturation are evident in 
childhood thyrotoxicosis [108-109]. Catch-up growth during thyroid hormone replacement treatment is marked but, unfortunately, may not be complete.

In animals, the dose-response relationship between thyroid hormone and linear growth, has been studied in prepubertal methimazole-induced hypothyroid monkeys. Subsequently, each animal has received 1, 2, 4, or 8 micrograms/kg per day of T4, IM, for 9 weeks. Methimazole administration decreases thyroid hormone and IGF-I levels and decreases leg growth rate. With increasing doses of exogenous T4, serum T4, T3, and IGF-I as well as lower leg growth rate increase significantly. Animals not given T4 has a $65 \%$ decrease in lower leg growth rate. Animals given 4 and 8 micrograms/kg per day T4 have $56 \%$ and $73 \%$ increases, respectively, in lower leg growth rate compared to baseline. Lower leg growth rate correlate better with serum T3, T4 and IGF-I. Serum IGF-I correlate with serum T3. This study proves that increased serum T4 and T3 levels cause progressive increases in growth velocity and IGF-I levels over a range from moderate hypothyroidism to moderate hyperthyroidism. Growth velocity and IGF-I levels correlate more strongly with the serum T3 than with the serum T4 level. [110]

In humans, many case studies and clinical research papers have investigated linear growth and pubertal maturation in neglected hypothyroidism. Their results can be summarised as following:

Case Report: An 11 year- old Egyptian girl has presented with severe short stature and mental retardation. Examination has revealed all features of cretinism with Height SDS (HtSDS) $=-7.6 \mathrm{SD}$, hypotonia, umbilical hernia, myxedematous face, and severe mental retardation with IQ $=30$. Low T4 and high TSH (Figure 1, Table 1) with bone age of 4 years are noted with marked epiphyseal dysgenesis, metaphyseal and vertebral changes. L-thyroxine therapy for ten years has been associated with significant and prolonged catch-up growth till the age of 20 years with near-normal adult stature compared to mid-parental height HtSDS = -0.9. Puberty started at the age of $15 \mathrm{y}$ and progressed over 4 years to full maturity. All radiological skeletal abnormalities were corrected after 5 years of thyroxine therapy. Significant increase in IGF-1 level and IGF-I response to GH stimulation was achieved early. In summary, complete catch up of growth with normalization of all radiological changes could occur even in neglected congenital hypothyroidism.

\begin{tabular}{ccccccc}
\hline $\begin{array}{c}\text { Age } \\
\text { [y] }\end{array}$ & Bone age [y] & HtSDS & GVSDS & $\begin{array}{c}\text { T4 } \\
\text { ug/dl }\end{array}$ & $\begin{array}{c}\text { TSH } \\
\mathrm{mIU} / \mathrm{ml}\end{array}$ & $\begin{array}{c}\text { IGF-I } \\
\mathrm{ng} / \mathrm{dl}\end{array}$ \\
\hline Birth & ND & 0 & ND & ND & ND & ND \\
\hline 11 & 3 & -7.6 & 3.4 & 0.5 & /100 & 25 \\
\hline 12 & 6 & -7.2 & 2 & 14.7 & 0.5 & 75 \\
\hline 14 & 10 & -6.5 & 6 & 14.00 & 0.6 & 98 \\
\hline 16 & 12 & -4.6 & 7 & 13.8 & 0.5 & \\
\hline 18 & 14 & -2.9 & 7 & 12.5 & 0.5 & \\
\hline 20 & 16 & -1.6 & ND & 13.9 & 0.8 &
\end{tabular}

Table 1. Growth and hormonal data of a patient with neglected hypothyroidism before and after treatment for 9 years. 
Kubicky et al. have described a patient who discontinued treatment few months for 3 years after neonatal diagnosis, and although treated till puberty she had significant growth retardation as an adult. Boersma et al. have described two children with untreated congenital hypothyroidism, and although they have experienced a marked catch-up growth, both of them have reached an adult height below their target height $[106,110]$.

Soliman et al. [73] have studied 15 children with neglected hypothyroidism aged $=6.4+/-4.2$ years. Patients had HtSDS $=-4.3+/-2.5$ and delayed bone age $(-4.5+/-2)$, with defective GH response to clonidine and low IGF-I concentration. After two years of treatment with L-thyroxine, their HtSDS has increased from $-4.3+/-2.5$ to $-2.7+/-2.3$. This has been associated with a significant improvement of their GH response to clonidine, increased IGF-I generation in response to GH stimulation. HtSDS increments correlated significantly with free T4 concentrations, and the growth velocity standard deviation score (GVSDS) s correlated significantly with increments in IGF-I concentrations with treatment. Therefore, in neglected hypothyroidism permanent height loss could not be prevented. The capacity to establish a significant, although incomplete, catch-up growth spurt is associated with significant recovery of GH -IGF-I axis and is proved to be possible, even after a long period of thyroid dysfunction. Incomplete catch-up growth after delayed treatment of infants and children with congenital hypothyroidism has been reported in other studies $[73,111]$.

In a retrospective study of 59 children with late diagnosis of hypothyroidism presented at different ages in the Endocrinology clinic of Alexandria University before the establishment of neonatal screening national program, Soliman et al. measured the HtSDS of patients before versus after 2 years of treatment. Results showed significant catch-up growth in those diagnosed during the first two years of life compared to those diagnosed after 6 years of life (Figure 2). Pubertal maturation was delayed in 10/21 patients and accelerated in 3/21. (Unpublished data by authors) (Table 2)

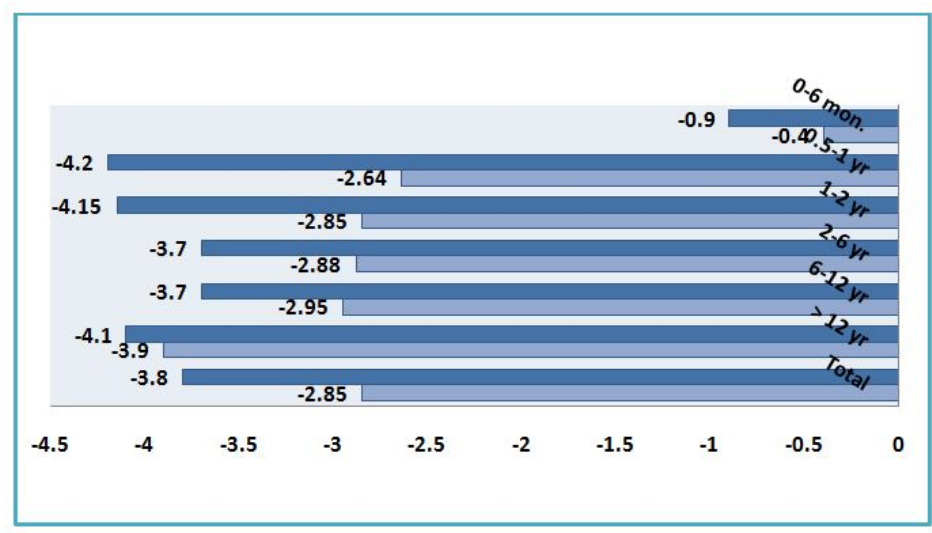

Figure 2. Height Standard Deviation Score [HtSDS] before [dark blue] and after [light blue] one year of treatment of neglected cases of hypothyroidism diagnosed at different ages. 


\begin{tabular}{lccc}
\hline & Delayed Puberty & Normal Puberty & Precocious Puberty \\
\hline Males $[n=9]$ & 6 & 2 & 1 \\
\hline Females $[n=12]$ & 4 & 6 & 2 \\
\hline Total $[n=21]$ & $10 / 21$ & $8 / 21$ & $3 / 21$
\end{tabular}

Table 2. Pubertal Data in neglected hypothyroidism

Collectively, these studies demonstrated clearly the deleterious effect of hypothyroidism on all stages of growth [infantile, childhood and pubertal phases] and the incomplete catch-up growth after treatment with thyroxine especially in older children.

\section{Growth in Congenital hypothyroidism treated at the neonatal period}

Forty years after the worldwide introduction of neonatal screening for congenital hypothyroidism, it is beyond doubt that early diagnosis and thyroxine treatment prevent brain damage. Although benefits of early treatment have never been proven in randomized placebocontrolled trials, studies that described the natural course of congenital hypothyroidism are considered sufficient evidence for its efficacy, at least in severe forms [73, 111-114]. After the introduction of the screening, several studies have reported a normal linear growth in infancy and childhood [115-117], while others have described a slight growth deceleration early in childhood in children with severe $\mathrm{CH}$ at diagnosis [118-120]. With respect to the achievement of a normal final height, some studies have suggested that the adequacy of L-thyroxine replacement in the first 6 months of life may influence the adult height of children with $\mathrm{CH}$ detected by newborn screening [121]. In contrast, other studies have found no correlation between severity at diagnosis, aetiology, or initial L-thyroxine dosage [122,123]. The only postnatal factor consistently found to be related to adult height has been the age at the start of treatment.

Salerno et al. [122] reported normal linear growth and onset and duration of puberty in both males and females $(n=55)$ with congenital hypothyroidism $(\mathrm{CH})$ detected by a neonatal screening program and treated with thyroxin. Their data have shown that the onset and the progression of puberty are independent of the aetiology, the severity of $\mathrm{CH}$ and the timing of the beginning of treatment. Girls treated with an initial amount of L-thyroxine (L-T4) $>8$ microg/kg per day have shown an earlier onset of puberty compared with girls treated with a lower initial dose of L-T4. However, both groups have attained a similar final height, which in both cases was above the target height. No significant relationship has been found between final height and severity of $\mathrm{CH}$ at diagnosis, initial L-T4 dosage or aetiology of hypothyroidism.

Soliman et al. [124, 125] have reported that hypothyroid patients $(n=45)$ diagnosed through the neonatal screening program have normal birth length, weight and head circumference compared to normal infants. These data rule out significant effect of foetal hypothyroidism on foetal growth. When treated with an initial T4 dosage (50 ug/day) with adjustment of T4 dose to maintain serum fT4 concentrations within the upper quartile of normal range and 
$\mathrm{TSH}<4 \mathrm{mIU} / \mathrm{ml}$, these children have adjustment (+/- $0.5 \mathrm{SD}$ ) of their mean HtSDS towards their mid-parental height SDS (MPHtSDS) only during the second year of life. In addition, child mean HtSDS is higher than MPHtSDS by an average of 0.4 SD between the 2 nd and $8^{\text {th }}$ year of life (Figure 3). Adachi et al. [126] have reported normal adult height of patients with $\mathrm{CH}$ detected by neonatal screening which was equivalent to that of the reference population and their target height.

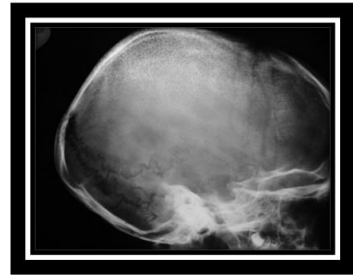

(A)

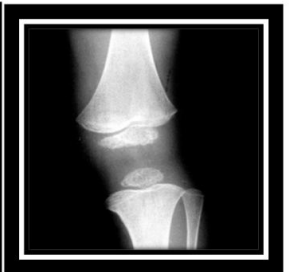

(B)

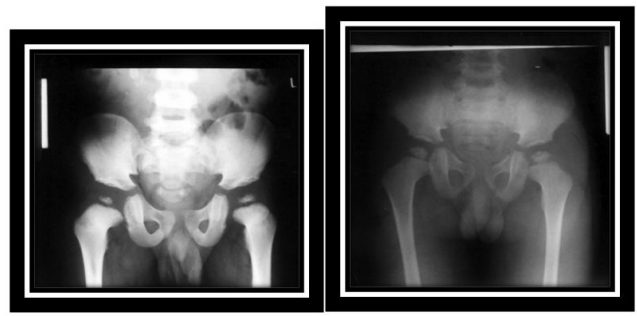

(C)

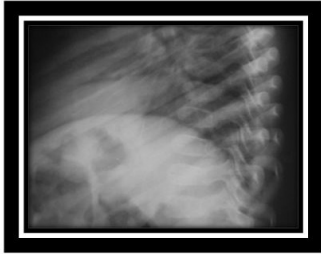

(E)
(D)

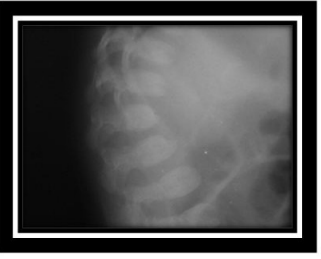

(F)

Figure 4. A: Skull X ray, lateral views, in a two- year-old child and 18-months old child demonstrating persistent wide anterior fontanelle, mild degree of brachycephaly in a relatively underdeveloped skull base with increased bone density, underdeveloped paranasal sinuses and slightly hypoplastic facial bones, enlarged sella turcica (Cherry sella), few wormian bones along lambdoid suture, relatively narrowed deploic space of parietal bones and overcrowded teeth. $B$ : AP view of knee demonstrating epiphyseal dysgenesis [irregularity and mild stippling] of the lower femoral and upper tibial epiphyses which are relatively small; and a delayed appearance of the upper fibular epiphysis for age of the patient. C, D. Plain X ray of the pelvis and both hips in a two-year-old child (C) and five-year-old (D) demonstrating epiphyseal dysgenesis of the upper femoral epiphyses (irregular flattened upper femoral epiphysis which are small for age of the patient; underdeveloped) with relatively shallow acetabular roofs and mild coxa vara deformity and relatively small (hypoplastic) iliac bones. E,F : Plain X ray of dorsolumbar region of two different patients demonstrating flattening of the vertebral bodies with relative osteoporosis leading to the appearance of "picture framing" of vertebral bodies ( $E$, and relatively wide disc spaces with typical bullet shape appearance of vertebral bodies (LV1 and LV2) and relatively small body of LV1 with anterior subluaxation of DV12 over LV1 leading to smooth gibbus deformity (F). 
Dickerman and de Vries [127] have found normal prepubertal and pubertal growth and achievement of normal adult height in children diagnosed through neonatal screening $(n=30)$ and have reported a significant correlation with parental height and the mean L-T4 daily dose administered over the first 6 months of treatment. A dose of at least 8.5 micrograms $/ \mathrm{kg} /$ day is recommended by these authors during this period.

Jones et al. [128] have studied growth of $314 \mathrm{CH}$ children according to initial daily dose of T4: Group 1 (25 ug, $\mathrm{n}=152$ ), Group 2 (30-40 ug, $\mathrm{n}=63$ ) and Group 3 (50 ug, $\mathrm{n}=99$ ). At 3 months weight, length and OFC SDS values have been $(-0.39,-0.35,0.09) ;(-0.30,-0.47,0.32)$; and $(-0.03,-0.13,0.18)$ for Groups 1,2 and 3, respectively, indicating no difference between the 3 doses on somatic growth between 3 months and 3 years. However, an initial T4 dose of $50 \mathrm{ug}$ daily has normalized thyroid function several months earlier than lowerdose regimes. These data has been confirmed by Salerno et al. [129] who have reported that higher dose has been shown to improve the IQ at 4 years of age, even in patients with severe $\mathrm{CH}$ at diagnosis.

These results suggest that conventional management of children with $\mathrm{CH}$ detected by neonatal screening with an initial dose $>8 \mathrm{ug} / \mathrm{kg} /$ day leads to normal infantile, childhood and pubertal growth with normal adult height and sexual development, and that the major factors determining adult height in these children are the familial genetic growth potential and good compliance to treatment. However, a still unsolved question is whether neonates with mild hypothyroidism benefit from treatment, too [130-134].

\section{Growth before and after Juvenile-Acquired hypothyroidism:}

In one study, hypothyroidism has been diagnosed and treated in 18 girls and six boys with prolonged juvenile hypothyroidism with a mean age of approximately 10.5 years and bone age $=6.1$ years. At diagnosis, the HtSDS scores are $-4+/-0.5$ in boys and $-3.12+/-0.5$ in girls. Treatment up to achieving the final adult has demonstrated incomplete catch-up (HTSDS = $-2.1+/-0.2$ ) with loss of 6-7 $\mathrm{cm}$ of the predicted adult height. Delay in therapy has been a critical factor in the deficit in the final adult height [138]. Another study following 20 girls and 9 boys with juvenile primary hypothyroidism until they reached final height has shown that at presentation the mean age of the boys was 9.5 years (bone age $=6.3$ years) and mean age of girls was 8.8 years (bone age $=5.4$ years). In the girls, the onset of puberty was 1.2 years later than the normal population but the duration of puberty was reduced. The pattern of growth in girls with treated hypothyroidism is abnormal as growth continues after menarche, at a time when normal girls have almost stopped growing (Figure 5). During the second year after menarche patients still have a mean growth velocity of $4.1 \mathrm{~cm} /$ year. These data suggest that juvenile primary hypothyroidism can result in a permanent height deficit and disharmony between growth and sexual maturation in girls, despite adequate treatment [134]. 


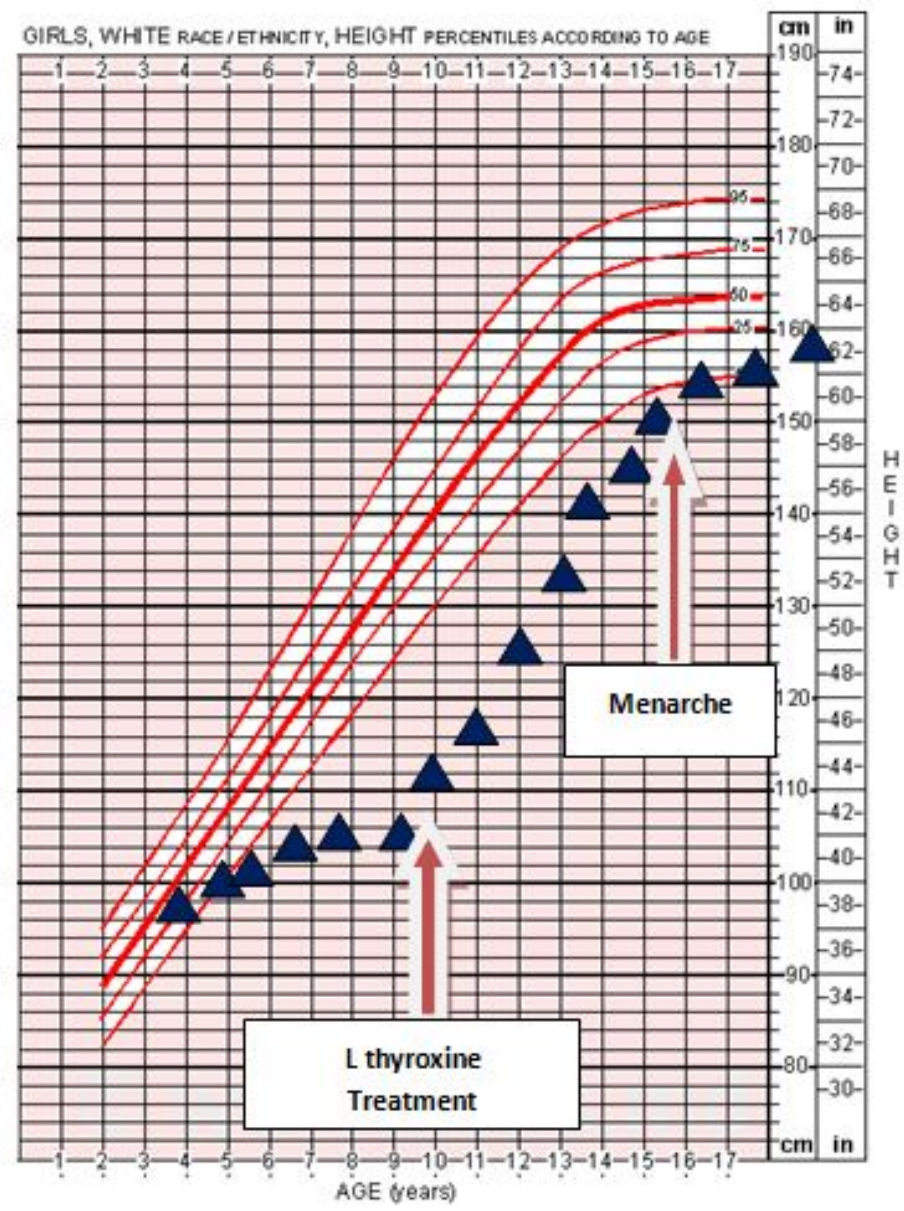

Figure 5. The Pattern of linear growth of a girl with juvenile hypothyroidism after treatment (Note the prolonged growth after menarche and short adult height)

In summary, thyroid hormones act on growth plate, bones and GH-IGF-I axis to modulate growth. These functions are mediated via many possible mechanisms including direct action on the chondrocytes, osteoblasts and mast cells, as well through interaction with other hormones and growth factors acting in endocrine, paracrine and autocrine fashions. Early diagnosis and treatment of infants born with congenital hypothyroidism, through neonatal screening, results in normal linear growth and attaining full growth potential. However, delayed diagnosis and treatment of congenital hypothyroidism and/or acquired hypothyroidism may result in partial catch-up growth and compromise final adult height of patients. 


\section{Author details}

Ashraf T. Soliman ${ }^{1 *}$, Vincenzo De Sanctis ${ }^{2}$ and El Said M.A. Bedair ${ }^{3}$

*Address all correspondence to: atsoliman@yahoo.com

1 Pediatric Endocrinology, Department of Pediatrics, Hamad General Hospital, Qatar

2 Pediatric and Adolescent Outpatient Clinic, Quisisana Hospital, Italy

3 AlKhor Hospital, Hamad Medical Center, Qatar

\section{References}

[1] Allain, T. J., \& Mc Gregor, A. M. (1993). Thyroid hormones and bone. Journal of Endocrinology, 139-9.

[2] Compston, J. E. (1993). Thyroid hormone therapy and the skeleton. Clinical Endocrinology, 39-519.

[3] Underwood, L. E., \& Van Wyk, J. J. (1992). Normal and aberrant growth. In: Williams Textbook of Endocrinology, 1079-1138, Eds JD Wilson \& DW Foster. Philadelphia, PA, USA: WB Saunders Company.

[4] Fisher, D., \& Plok, D. (1995). Thyroid disease in the fetus, neonate and child. In Endocrinology, 78-798, Ed LJ DeGroot. Philadelphia,PA, USA: WB Saunders.

[5] Miell, J. P., Taylor, A. M., Zini, M., Maheshwari, H. G., Ross, R. J. M., \& Valcavi, R. (1993). Effects of hypothyroidism and hyperthyroidism on insulin-like growth factors [IGFs] and growth hormone and IGF binding proteins. J Clin Endocrinol Metab, 76, 950-953.

[6] Burstein, P. J., Draznin, B., Johnson, C. J., \& Schalch, DS. (1979). The effects of hypothyroidism on growth, serum growth hormone, the growth hormone dependent somatomedin, insulin-like growth factor, and its carrier protein in rats. Endocrinology, $104,1107-1111$.

[7] Harakawa, S., Yamashita, S., \& Tobinaga, T. (1990). In vivo regulation of hepatic insulin ike growth factor 1 mRNA with thyroid hormone. Endocrinol Jpn, 37, 205-211.

[8] Näntö-Salonen, K., Glasscock, G. F., \& Rosenfeld, R. G. (1991). The effects of thyroid hormone on insulin-like growth factor [IGF] and IGF-binding protein [IGFBP] expression in the neonatal rat: prolonged high expression of IGFBP-2 in methimazoleinduced congenital hypothyroidism. Endocrinology, 129, 2563-2571. 
[9] Gallo, G., de Marchis, M., Voci, A., \& Fugassa, E. (1991). Expression of hepatic mRNAs for insulin-like growth factors-I and-II during the development of hypothyroid rats. J Endocrinol, 131, 367-372.

[10] Näntö-Salonem, Rosenfeld. R. G. (1992). Insulin-like growth factor binding protein expression in the hypothyroid rat is age dependent. Endocrinology, 131, 1489-1496.

[11] Ramos, S., Goya, L., Alvarez, C., \& Pascual-Leone, A. M. (1998). Mechanism of Hypothyroidism Action on Insulin-Like Growth Factor-I and-II from Neonatal to Adult Rats: Insulin Mediates Thyroid Hormone Effects in the Neonatal Period. Endocrinolo$g y, 139,12(12), 4782-4792$.

[12] Näntö-Salonen, K., Muller, H. L., Hoffman, A. R., Vu, T. H., \& Rosenfeld, R. G. (1993). Mechanism of thyroid hormone action on the insulin-like growth factor system: all thyroid hormone effects are not growth hormone mediated. Endocrinology, 132, 781-788.

[13] Ikeda, T., Fujiama, K., \& Takeuchi, T. (1989). Effect of thyroid hormone on somatomedin C release from perfused rat liver. Experientia, 45, 170-180.

[14] Miell, J. P., Taylor, A. M., Zini, M., Maheshwari, H. G., Ross, R. J. M., \& Valcavi, R. (1993). Effects of Hypothyroidism and Hyperthyroidism on Insulin-Like Growth Factors [IGFs] and Growth Hormone- and IGF-Binding Proteins. J Clin Endocrinol Metab, 76, 950-5.

[15] Gaspard, T., Wondergem, R., Hamamdzic, M., \& Klitgaard, H. M. (1978). Serum somatomedin stimulation in thyroxine-treated hypophysectomized rats. Endocrinology, 102, 606-611.

[16] Schmid, Christoph., Zwimpfer, Cornelia., Brändle, Michael., Krayenbühl-Alexandre, Pierre., Zapf, Jürgen., \& Wiesli, Peter. (2006). Effect of thyroxine replacement on serum IGF-I, IGFBP-3 and the acid-labile subunit in patients with hypothyroidism and hypopituitarism. Clinical Endocrinology, 65(6), December, 706-711.

[17] Buchanan, C. R., Stanhope, R., Adlard, P., Jones, J., Grant, D. B., \& Preece, MA. (1988). Gonadotropin, growth hormone and prolactin secretion in children with primary hypothyroidism. Clin Endocrinol [Oxf], 29, 427-436.

[18] Chernausek, S. D., Underwood, L. E., Utiger, R. D., \& Van Wijk, J. J. (1983). Growth hormone secretion and plasma somatomedin-C in primary hypothyroidism. Clin Endocrinol [Oxf], 19, 337-344.

[19] Burstein, P. J., Draznin, B., Johnson, C. J., \& Schalch, DS. (1979). The effect of hypothyroidism on growth, serum growth hormone, the growth hormone-dependent somatomedin, insulin-like growth factor, and its carrier protein in rats. Endocrinology, 104, 1107-1111.

[20] Bucher, H., Prader, A., \& Illig, R. (1985). Head circumference, height, bone age and weight in 103 children with congenital hypothyroidism before and during thyroid hormone replacement. Helv Paediatr Acta, 40, 305-316. 
[21] Harnack, G. A., Tanner, J. M., Whitehouse, R. H., \& Rodriguez, C. A. (1972). Catchup in height and skeletal maturity in children on long-term treatment for hypothyroidism. Z Kinderheilk, 112, 1-17.

[22] Rivkees, S. A., Bode, H. H., \& Crawford, J. D. (1988). Long-term growth in juvenile acquired hypothyroidism: the failure to achieve normal adult stature. $N$ Engl J Med, 318, 599-602.

[23] Boersma, B., Otten, B. J., Stoelinga, G. B. A., \& Wit, J. M. (1996). Catch-up growth after prolonged hypothyroidism. Eur J Pediatr, 155, 362-367.

[24] Pantsiotou, S., Stanhope, R., Uruena, M., Preece, MA, \& Grant, D. B. (1991). Growth prognosis and growth after menarche in primary hypothyroidism. Arch Dis Child, 66, 838-840.

[25] Weiss, R. E., \& Refetoff, S. (1996). Effect of thyroid hormone on growth: lessons from the syndrome of resistance to thyroid hormone. Endocrinol Metab Clin North Am, 27, 719-730.

[26] Soliman, A. T., \& Awwa, A. (2011). Catch-up growth role of GH-IGF-I and thyroxine. Victor R. Preedy ed., Handbook of Growth and Growth Monitoring in Health and Disease. Chapter V, New York: Springer, 935-965.

[27] Boersma, B., Otten, B. J., Stoelinga, G. B. A., \& Wit, J. M. (1996). Catch-up growth after prolonged hypothyroidism. Eur J Pediatr, 155, 362-367.

[28] Wi, J. M., \& Boersma, B. (2002). Catch-up growth: definition, mechanisms, and models. J Pediatr Endocrinol Metab, Dec, 15(5), 1229-41.

[29] Williams, J. P. G. (1981). Catch-up growth. J Embryol Exp Morph, 65, 89-101.

[30] Holder, N. (1981). Regeneration and compensatory growth. Br Med Bull, 37, 227-232.

[31] Lampl, M., Veldhuis, JD, \& Johnson, M. L. (1992). Saltation and stasis: a model of human growth. Science, 258, 801-803.

[32] De Luca, F. (2006). Impaired growth plate chondrogenesis in children with chronic illnesses. Pediatr Res., May, 59(5), 625-9.

[33] Williams, G. R., Robson, H., \& Shalet, S. M. (1998). Thyroid hormone actions on cartilage and bone: interactions with other hormones at the epiphyseal plate and effects on linear growth. J Endocrinol, 157, 391-403.

[34] Price, J. S., Oyajobi, B. O., \& Russell, R. G. G. (1994). The cell biology of bone growth. Eur J Clin Nutr, 48, S131-49.

[35] Lanske, B., Karaplis, A. C., Lee, K., et al. (1996). PTH/PTHrP receptor in early development and Indian hedgehog-regulated bone growth. Science, 273, 663-6.

[36] Vortkamp, A., Lee, K., Lanske, B., Segre, G. V., Kronenberg, H. M., \& Tabin, C. J. (1996). Regulation of rate of cartilage differentiation by Indian hedgehog and PTHrelated protein. Science, 273, 613-22. 
[37] Bassett, Duncan J. H., \& Williams, Graham R. (2009). The skeletal phenotypes of TR $\alpha$ and TR $\beta$ mutant mice. J Mol Endocrinol April, 1, 42-269.

[38] Lewinson, D., Harel, Z., Shenzer, P., Silbermann, M., \& Hochberg, Z. (1989). Effect of thyroid hormone and growth hormone on recovery from hypothyroidism of epiphyseal growth plate cartilage and its adjacent bone. Endocrinology, 124, 937-45.

[39] Siebler, T., Robson, H., Bromley, M., Stevens, D. A., Shalet, S. M., \& Williams, G. R. (2002). Thyroid status affects number and localization of thyroid hormone receptor expressing mast cells in bone marrow. Bone, 30, 259-66.

[40] Fraichard, A., Chassande, O., Plateroti, M., Roux, J. P., Trouillas, J., Dehay, C., Legrand, C., Gauthier, K., Kedinger, M., Malaval, L., Rousset, B., \& Samarut, J. (1997). The T3R a gene encoding a thyroid hormone receptor is essential for post-natal development and thyroid hormone production. EMBO J, 16, 4412-4420.

[41] Buckler, Jm., Willgerodt, H., \& Keller, E. (1986). Growth In Thyrotoxicosis. Arch Dis Child, 61, 464-471.

[42] Leger, J., \& Czernichow, P. (1989). Congenital Hypothyroidism: Decreased Growth Velocity In The Fi Rst Weeks Of Life. Biol Neonate, 55, 218-223.

[43] Stevens, Da., Hasserjian, Rp., Robson, H., Siebler, T., Shalet, Sm., \& Williams, Gr. (2000). Thyroid Hormones Regulate Hypertrophic Chondrocyte Differentiation And Expression Of Parathyroid Hormone- Related Peptide And Its Receptor During Endochondral Bone Formation. J Bone Miner Res, 15, 2431-2442.

[44] Robson, H., Siebler, T., Stevens, D. A., Shalet, S. M., \& Williams, G. R. (2000). Thyroid Hormone Acts Directly On Growth Plate Chondrocytes To Promote Hypertrophic Differentiation And Inhibit Clonal Expansion And Cell Proliferation. Endocrinology, $141,3887-3897$.

[45] Ishikawa, Y., Genge, B. R., Wuthier, R. E., \& Wu, L. N. (1998). Thyroid hormone inhibits growth and stimulates terminal differentiation of epiphyseal growth plate chondrocytes. J Bone Miner Res, Sep, 13(9), 1398-411.

[46] Shen, S., Berry, W., Jaques, S., Pillai, S., \& Zhu, J. (2004). Differential expression of iodothyronine deiodinase type 2 in growth plates of chickens divergently selected for incidence of tibial dyschondroplasia. Anim Genet, 35, 114-8.

[47] Miura, M., Tanaka, K., Komatsu, Y., Suda, M., Yasoda, A., Sakuma, Y., et al. (2002). Thyroid hormones promote chondrocyte differentiation in mouse ATDC5 cells and stimulate endochondral ossification in fetal mouse tibias through iodothyronine deiodinases in the growth plate. J Bone Miner Res, 17, 443-54.

[48] Kronenberg, H. M. (2003). Developmental regulation of the growth plate. Nature, 423, 332-6. 
[49] Kronenberg, H. M., \& Chung, U. (2001). The parathyroid hormone-related protein and Indian hedgehog feedback loop in the growth plate. Novartis Found Symp, 232, 144-52.

[50] Stevens, D. A., Hasserjian, R. P., Robson, H., Siebler, T., Shalet, S. M., \& Williams, G. R. (2000). Thyroid hormones regulate hypertrophic chondrocyte differentiation and expression of parathyroid hormone-related peptide and its receptor during endochondral bone formation. J Bone Miner Res, 15, 2431-42.

[51] Okubo, Y., \& Reddi, A. H. (2003). Thyroxine downregulates Sox9 and promotes chondrocyte hypertrophy. Biochem Biophys Res Commun, 306, 186-90.

[52] Ballock, R. T., Zhou, X., Mink, L. M., Chen, D. H., Mita, B. C., \& Stewart, M. C. (2000). Expression of cyclin-dependent kinase inhibitors in epiphyseal chondrocytes induced to terminally differentiate with thyroid hormone. Endocrinology, 141, 4552-7.

[53] De Luca, F., \& Baron, J. (1999). Control of Bone Growth by Fibroblast Growth Factors. Trends Endocrinol Metab, 10, 61-5.

[54] Ornitz, D. M., \& Marie, P. J. (2002). FGF signaling pathways in endochondral and intramembranous bone development and human genetic disease. Genes Dev, 16, 1446-65.

[55] Stevens, D. A., Harvey, C. B., Scott, A. J., O'Shea, P. J., Barnard, J. C., Williams, A. J., et al. (2003). Thyroid hormone activates fibroblast growth factor receptor-1 in bone. Mol Endocrinol, 17, 1751-66.

[56] Gauthier, K., Plateroti, M., Harvey, C. B., Williams, G. R., Weiss, R. E., Refetoff, S., et al. (2001). Genetic analysis reveals different functions for the products of the thyroid hormone receptor alpha locus. Mol Cell Biol, 21, 4748-60.

[57] Schlessinger, J., Plotnikov, A. N., Ibrahimi, O. A., Eliseenkova, A. V., Yeh, B. K., Yayon, A., et al. (2000). Crystal structure of a ternary FGF-FGFR-heparin complex reveals a dual role for heparin in FGFR binding and dimerization. Mol Cell, 6, 743-50.

[58] Quarto, R., Campanile, G., Cancedda, R., \& Dozin, B. (1992). Thyroid hormone, insulin, and glucocorticoids are sufficient to support chondrocyte differentiation to hypertrophy: a serum-free analysis. J Cell Biol, 119, 989-995.

[59] Lewinson, D., Harel, Z., Shenzer, P., Silbermann, M., \& Hochberg, Z. (1989). Effect of thyroid hormone and growth hormone on recovery from hypothyroidism of epiphyseal growth plate cartilage and its adjacent bone. Endocrinology, 124, 937-45.

[60] Cecillia-Hubner, Camacho. (2010). Normal Physiology of Growth Hormone and Insulin-Like Growth Factors in Childhood. Endotext., February, Chapter 5a, http:// www.endotext.org/neuroendo/neuroendo5a/neuroendo5a.htm.

[61] Sriskantharajah, S., O'Shea, P. J., Yao, H., Suzuki, H., Cheng, S. Y., \& Williams, G. R. (2004). Regulation of the growth hormone [GH] and insulin-like growth factor-1 
[IGF-1] paracrine pathway by thyroid hormone [T3] during bone development. Endocrine, Abstracts 7, 142.

[62] Ik, Soo. Kim. Diagnostic Imaging of Musculoskeletal Diseases a Systematic Approach. In Akbar Bonakdarpour,William R.Reinus, Jasvir S. Khurana, eds. Springer, New York- Dordrecht- Heidelberg-London, 10.1007/978-1-59745-355-4.

[63] Wexler, J. A., \& Sharretts, J. (2007). Thyroid and bone. Endocrinol Metab Clin North Am, 36, 673-705.

[64] Bassett, J. H. D., \& Williams, G. R. (2003). The molecular actions of thyroid hormones in bone. Trends Endocrinol Metab, 14, 356-64.

[65] Greet, Roef., Bruno, Lapauw., Stefan, Goemaere., Hans, Zmierczak., Tom, Fiers., Jean-Marc, Kaufman., \& Youri, Taes. (2011). Thyroid hormone status within the physiological range affects bone mass and density in healthy men at the age of peak bone mass. Eur J Endocrinol, Jun, 164(6), 1027-34.

[66] High, W. B., Capen, C. C., \& Black, H. E. (1981). Effects of thyroxine on cortical bone remodeling in adult dogs: a histomorphometric study. Am J Pathol, March, 102(3), 438-446.

[67] Farquharson, C. (2011). Social networking between cells of the foetal skeleton: The importance of thyroid hormones. J Endocrinol, Aug, 210(2), 135-6, 2011 Jun 16.

[68] Toivonen, J., Tahtela, R., Laitinen, K., Risteli, J., \& Valimaki, MJ. (1998). Markers of bone turnover in patients with differentiated thyroid cancer with and following withdrawal of thyroxine suppressive therapy. Eur J Endocrinol, 138(6), 667-673.

[69] Vestergaard, P., \& Mosekilde, L. (2003). Hyperthyroidism, Bone Mineral, and Fracture Risk- a meta-analysis. Thyroid, 13, 585-593.

[70] Akalin, A., Colakt, O., Alatast, O., \& Efe, B. (2002). Bone remodeling markers and serum cytokines in patients with hyperthyroidism. J Clin Endocrinology, 57, 125-129.

[71] Dhanwal, D. K., Dennison, E. M., Harvey, N. C., \& Cooper, C. (2011). epidemiology of hip fracture: worldwide geographic distribution. Indian J Orthop, 45, 15-2.

[72] Botella-Carretero, J. I., varez-Blasco, F., San Millan, J. L., \& Escobar-Morreale, H. F. (2007). Thyroid hormone deficiency and postmenopausal status independently increase serum osteoprotegerin concentrations in women. Eur J Endocrinol, 156(5), 539-545.

[73] Soliman, A. T., Omar, M., El Awwa, A., Rizk, M. A., El Alaily, R., \& Bedair, E. M. A. (2008). Linear Growth, Growth-Hormone Secretion And Igf-I Generation In Children With Neglected Hypothyroidism Before And After Thyroxine Replacement. J Trop Ped, 54, 347-349.

[74] Elaine, Murphy. (2004). Thyroid Hormone and Bone Development. Hot Thyroidology [1], http://www.hotthyroidology.com, May. 
[75] Bassett, J. H. D., Swinhoe, R., Chassande, O., Samarut, J., \& Williams, G. R. (2006). Thyroid Hormone Regulates Heparan Sulfate Proteoglycan Expression in the Growth Plate. Endocrinology, 147(1), 295-305.

[76] Lewinson, D., Harel, Z., Shenzer, P., Silbermann, M., \& Hochberg, Z. (1989). Effect Of Thyroid Hormone And Growth Hormone On Recovery From Hypothyroidism Of Epiphyseal Growth Plate Cartilage And Its Adjacent Bone. Endocrinology, 124, 937-945.

[77] Ola, Nilsson., Rose, Marino., \& Francesco De, Luca. (2005). Moshe Phillip Endocrine Regulation Of The Growth Plate. Horm Res, 64, 157-165.

[78] Ohlsson, C., Nilsson, A., Isaksson, O., Bentham, J., \& Lindahl, A. (1992). Effects of triiodothyronine and insulin-like growth factor-I [IGF-I] on alkaline phosphatase activity, $[3 \mathrm{H}]$ thymidine incorporation and IGF-I receptor mRNA in cultured rat epiphyseal chondrocytes. J Endocrinol, Oct, 135(1), 115-23.

[79] Cavaliere, H., Knobel, M., \& Medeiros-Neto, G. (1987). Effect of Thyroid Hormone Therapy on Plasma Insulin-Like Growth Factor I Levels in Normal Subjects, Hypothyroid Patients and Endemic Cretins. Hormone Research, 25(3).

[80] Nato-Salonen, K., Muller, H. L., Hoffman, A. R., Vu, T. H., \& Rosenfeld, R. G. (1993). Mechanisms of thyroid hormone action on the insulin-like growth factor system: all thyroid hormone effects are not growth hormone mediated. Endocrinology, 132, 781-8.

[81] Gaspard, T., Wondergem, R., Hamamdzic, M., \& Klitgaard, H. M. (1978). Serum somatomedin stimulation in thyroxine treated hypophysectomized rat. Endocrinology, 102, 606-11.

[82] Ramos, S., Goya, L., Alvarez, C., Martin-Leone, MA, \& Pascual, A. M. (2001). Effect of thyroxine administration on the IGF/IGF binding protein system in neonatal and adult thyroidectomized rats. J Endocrinol, 169, 111-22.

[83] Ikeda, T., Fujiyama, K., Hoshino, T., Tanaka, Y., Takeuchi, T., Mashiba, H., \& Tominaga, M. (1999). Stimulating effect of thyroid hormone on insulin-like growth factor-I release and synthesis by perfused rat liver. Growth Regul, 1, 39-41.

[84] Binoux, M., Faivre-Bauman, A., Lassarre, C., Barret, A., \& Tixier-Vidal, A. (1985). Triiodothyronine stimulates the production of insulin-like growth factor [IGF] by fetal hypothalamus cell cultured in serum-free medium. Brain Res, 353, 319-21.

[85] Li, J., Owens, J. A., Owens, P. C., Saunders, J. C., Fowden, A. L., \& Gilmour, R. S. (1996). The ontogeny of hepatic growth hormone receptor and insulin-like growth factor-I gene expression in the sheep fetus during late gestation: developmental regulation by cortisol. Endocrinology, 137, 1650-7.

[86] Liggins, G. C. (1994). The role of cortisol in preparing the fetus for birth. Reprod Fertil Dev, 6, 141-50. 
[87] Forhead, A. J., Li, J., Sunders, J. C., Dauncey, MJ, Gilmour, R. S., \& Fowden, A. L. (2000). Control of ovine hepatic growth hormone receptor and insulin-like growth factor-I By thyroid hormones in utero. Am J Physiol Endocrinol Metab, 278, 1166-74.

[88] Polk, D., Cheromcha, D., Reviczky, A., \& Fisher, D. A. (1989). Nuclear thyroid hormone receptors: ontogeny and thyroid hormone effects on sheep. Am J Physiol Endocrinol Metab, 256, 543-9.

[89] Moro, L., Marra, E., Capuano, F., \& Greco, M. (2004). Thyroid hormone treatment of hypothyroid rats restores the regenerative capacity and the mitochondrial membrane permeability properties of the liver after partial hepatectomy. Endocrinology, 145, $5121-8$.

[90] Alisi, A., Demori, I., Spagnuolo, S., Pierantozzi, E., Fugassa, E., \& Leoni, S. (2005). Thyroid status affects rat liver regeneration after partial hepatectomy by regulating cell cycle and apoptosis. Cellular Phsiology and Biochemistry, 15, 69-76.

[91] Canavan, J. P., Holt, J., Easton, J., Smith, K., \& Goldspink, D. F. (1994). Thyroid-induced changes in the growth of the liver, kidney, and diaphragm of neonatal rats. $J$ cell Physial, 161, 49-54.

[92] Wolf, M., Ingbar, S. H., \& Moses, A. C. (1989). Thyroid hormone and growth hormone interact to regulate insulin-like growth factor-I messenger ribonucleic acid and circulating levels in the rat. Endocrinology, 125, 2905-14.

[93] Jorgensen, J. O., Moller, J., Laursen, T., Orskov, H., Christiansen, J. S., \& Weeke, J. (1994). Growth hormone administration stimulates energy expenditure and extrathyroidal conversion of thyroxine to triiodothyronine in a dose-dependent manner and suppresses circadian thyrotrophin levels: studies in GH-deficient adults. Clin Endocrinol [Oxf]., Nov, 41(5), 609-14.

[94] Akin, F., Yaylali, G. F., Turgut, S., et al. (2009). Growth hormone/insulin like growth factor axis in patients with subclinical thyroid dysfunction. Growth Horm IGF Res, 19, 252-255.

[95] Valcavi, R., Valente, F., Dieguez, C., et al. (1993). Evidence against depletion if the growth hormone releasable pool in human primary hypothyroidism: studies with GH-releasing hormone, pyridostigmine and arginine. J Clin Endocrinol Metab, 77, 616-20.

[96] Iranmanesh, A., Lizarralde, G., Johnson, M. L., \& Veldhuis, JD. (1991). Nature of altered growth hormone secretion in hyperthyroidism. J Clinical Endocrinol Metab, 72, 108-115.

[97] Chernausek, S. D., \& Turner, R. (1989). Attenuation of spontaneous nocturnal growth hormone secretion in children with hypothyroidism and its correlation with plasma insulin like growth factor 1 concentrations. J Ped, 114, 968-972. 
[98] Lakatos, P., Foldes, J., Nagy, Z., et al. (2000). Serum insulin-like growth factor-1, insulin-like growth factor binding proteins, and bone mineral content in hyperthyroidism. Thyroid, 10, 417-423.

[99] Inukai, T., Takanashi, K., Takabayashi, K., et al. (1999). Thyroid hormone modulates insulin-like growth factor-1 [IFG-1] and IGF-binding protein-3, without mediation by growth hormone, inpatients with autoimmune thyroid diseases. Horm Metab Res, 20, 213-216.

[100] Miell, J. P., Taylor, A. M., Zini, M., et al. (1993). Effects of hypothyroidism on insulinlike growth factors [IGFs] and growth hormone and IGF-binding proteins. Journal of Clinical Endocrinology and Metabolism, 76, 950-5.

[101] Gafni, R. I., Weise, M., Robrecht, D. T., Meyers, J. L., Barnes, K. M., De -Levi, S., \& Baron, J. (2001). Catch-up growth is associated with delayed senescence of the growth plate in rabbits. Pediatr Res., Nov, 50(5), 618-23.

[102] Marino, R., Hegde, A., Barnes, Km., Schrier, L., Emons, Ja., Nilsson, O., \& Baron, J. (2008). Catch-Up Growth After Hypothyroidism Is Caused By Delayed Growth Plate Senescence. Endocrinology., Apr, 149(4), 1820-8.

[103] Roy, E., \& Weiss, Samuel. Refet. Resistance to Thyroid Hormone [RTH] in the Absence of Abnormal Thyroid Hormone Receptor [TR] [nonTR-RTH]. Hot Thyroidol. 09/09. Online, 0207-5220, 2075-220.

[104] Pohlenz, J., Weiss, R. E., Macchia, P. E., Pannain, S., Lau, I. T., Ho, H., \& Refetoff, S. (1999). Five new families with resistance to thyroid hormone not caused by mutations in the thyroid hormone receptor beta gene. J Clin Endocrinol Metab, 84, 3919-3928.

[105] Rivkees, S. A., Bode, H. H., \& Crawford, J. D. (1988). Long-term growth in juvenile acquired hypothyroidism: the failure to achieve normal adult stature. $N$ Engl J Med, 318, 599-602, Abstract.

[106] Boersma, B., Otten, B. J., Stoelinga, G. B. A., \& Wit, J. M. (1996). Catch-up growth after prolonged hypothyroidism. Eur J Pediatr, 155, 362-367.

[107] Segni, M., Leonardi, E., Mazzoncini, B., Pucarelli, I., \& Pasquino, A. M. (1999). Special features of Graves' disease in early childhood. Thyroid, 9, 871-877.

[108] Hulse, J. A. (1984). Outcome for congenital hypothyroidism,. Archives of Disease in Childhood, 59(1), 23-29.

[109] Segni, M., Leonardi, E., Mazzoncini, B., Pucarelli, I., \& Pasquino, A. M. (1999). Special features of Graves' disease in early childhood. Thyroid, 9, 871-877.

[110] Boersma, B., \& Wit, J. M. (1997). Catch-up growth. Endocr Rev, 18, 646-61.

[111] Geraldo, A., Medeiros-Neto, L. M., de Assis, William., Nicolau, A., et al. (1965). Congenital and Juvenile Hypothyroidism Due to Thyroid Dysgenesis. J Nuclear medicine, 6, 275-286. 
[112] Rita, Ann., Kubicky, Evan. Weiner, Carlson, Bronwyn., \& De Luca, Francesco. (2012). Effect of Prolonged Discontinuation of L-Thyroxine Replacement in a Child with Congenital Hypothyroidism. Case Reports in Endocrinology, Article ID 841947, 5 pages, $10.1155 / 2012 / 841947$.

[113] Klein, R. Z., \& Mitchell, M. L. (2000). Hypothyroidism in infants and children. Neonatal screening. Braverman LE, Utiger RD, eds. Werner, Ingbar's the thyroid: a fundamental and clinical text. 8th ed. Philadelphia: Lippincott Williams \& Wilkins, 973-988.

[114] Derksen-Lubsen, G., \& Verkerk, P. H. (1996). Neuropsychologic development in early treated congenital hypothyroidism: analysis of literature data. Pediatr Res, 39, 561-566.

[115] Bucher, H., Prader, A., \& Illig, R. (1985). Head circumference, height, bone age and weight in 103 children with congenital hypothyroidism before and during thyroid hormone replacement,. Helvetica Paediatrica Acta, 40(4), 305-316, View at Scopus.

[116] Moschini, L., Costa, P., Marinelli, E., et al. (1986). Longitudinal assessment of children with congenital hypothyroidism detected by neonatal screening,. Helvetica Paediatrica Acta, 41(5), 415-424.

[117] Moreno, L., Ythier, H., Loeuille, G. A., Lebecq, M. F., Dhondt, J. L., \& Farriaux, J. P. (1989). Etude de la croissance et de la maturation osseuse au cours de l'hypotyroidie congenitale depistee en periode neonatale. A propos de 82 observations. Archives Francaises de Pediatrie, 46(10), 723-728, View at Scopus.

[118] Grant, D. B. (1994). Growth in early treated congenital hypothyroidism,. Archives of Disease in Childhood, 70(6), 464-468, View at Scopus.

[119] Aronson, R., Ehrlich, R. M., Baily, J. D., \& Rovet, J. F. (1990). Growth in children with congenital hypothyroidism detected by neonatal screening. Journal of Pediatrics, 116(1), 33-37, View at Publisher, View at Google Scholar, View at Scopus.

[120] Heyerdahl, S., Ilicki, A., Karlberg, J., Kase, B. F., \& Larsson, A. (1997). Linear growth in early treated children with congenital hypothyroidism,. Acta Paediatrica, 86(5), 479-483, View at Scopus.

[121] Dickerman, Z., \& De Vries, L. (1997). Prepubertal and pubertal growth, timing and duration of puberty and attained adult height in patients with congenital hypothyroidism $[\mathrm{CH}]$ detected by the neonatal screening programme for $\mathrm{CH}$-a longitudinal study,". Clinical Endocrinology, 47(6), 649-654, View at Scopus.

[122] Salerno, M., Micillo, M., Di Maio, S., et al. (2001). Longitudinal growth, sexual maturation and final height in patients with congenital hypothyroidism detected by neonatal screening,. European Journal of Endocrinology, 145(4), 377-383, View at Scopus.

[123] Bain, P., \& Toublanc, J.E. (2002). Adult height in congenital hypothyroidism: prognostic factors and the importance of compliance with treatment. Hormone Research, 58(3), 136-142. 
[124] Soliman, A., Alsaied, A., Elawwa, A., \& Sabt, A. (2012). Linear growth of children with congenital hypothyroidism detected by neonatal screening compared to normal children and their mid-parental height. Endocrine Abstracts, 29, 1303.

[125] Ashraf, T. Soliman, Azzam, S., Ahmed., El Awwa, Saleem, Wael., \& Aml, Sabt. (2012). Linear growth and neurodevelopmental outcome of children with congenital hypothyroidism detected by neonatal screening: A controlled study. Indian J Endocrinol Metab., Jul-Aug, 16(4), 565-568.

[126] Adachi, M., Asakura, Y., \& Tachibana, K. (2003). Final height and pubertal growth in Japanese patients with congenital hypothyroidism detected by neonatal screening. Acta Paediatr., Jun, 92(6), 698-703.

[127] Dickerman, Z., \& de Vries, L. (1997). Prepubertal and pubertal growth, timing and duration of puberty and attained adult height in patients with congenital hypothyroidism $[\mathrm{CH}]$ detected by the neonatal screening programme for $\mathrm{CH}$--a longitudinal study. Clinical Endocrinology, 47(6), 649-54.

[128] Jones, J. H., Gellén, B., Paterson, W. F., Beaton, S., \& Donaldson, MD. (2008). Effect of high versus low initial doses of L-thyroxine for congenital hypothyroidism on thyroid function and somatic growth. Arch Dis Child., Nov, 93(11), 940-4, 2008 May 2.

[129] Salerno, M., Militerni, R., Bravaccio, C., Micillo, M., Capalbo, D., \& Di Tenore, A. (2002). Effect of different starting doses of levothyroxine on growth and intellectual outcome at four years of age in congenital hypothyroidism. Thyroid, Jan, 12(1), 45-52.

[130] Daliva, A. L., Linder, B., Di Martino-Nardi, J., \& Saenger, P. (2000). Three-year follow-up of borderline congenital hypothyroidism. J Pediatr, 136, 53-56.

[131] Kohler, B., Schnabel, D., Biebermann, H., \& Gruters, A. (1996). Transient congenital hypothyroidism and hyperthyrotropinemia: normal thyroid function and physical development at the ages of 6-14 years. J Clin Endocrinol Metab, 81, 1563-1567.

[132] Rapaport, R. (2000). Congenital hypothyroidism: expanding the spectrum. J Pediatr, 136, 10-12.

[133] Rivkees, S. A., Bode, H. A., \& Crawford, J. D. (1988). Long-Term Growth in JuvenileAcquired Hypothyroidism. N Engl J Med, 318, 599-602.

[134] Pantsiouou, S., Stanhope, R., Uruena, M., Preece, M. A., \& Grant, D. B. (1991). Growth prognosis and growth after menarche in primary hypothyroidism. Arch Dis Child., July, 66(7), 838-840. 